The highest values have been found in Wales, Northern Ireland, Scotland and far-western Eng. land, but even these would not lead to the annual average specified by the Medical Research Council unless they continued for at least a further soven months or more. Regional differences can result not only from climatic and geogrophical factors but also from differences in the diet of cattle. The quantity of iodine-131 which they consume depends primarily on the quantity of fresh grass which they eat; thus, recently deposited fission products enter milk less readily when, owing to the onset of winter, cattle are provided with increasing quantities of other foods. In 1958, after the previous series of weapons trials in the Arctic, this effect was marked from the middle of November onwards, and results from Scotland suggest that it is occurring again. It cannot, however, be assumed that the contamination of milk will decrease steadily in the future, because for some weeks after the detonation of nuclear weapons the rate of deposition may vary widely depending on meteorological factors. A careful watch will therefore be maintained so long as appreciable levels of contamination remain.

\section{Paul Instrument Fund Grants}

Awards of grants by the Paul Instrument Fund Committee have been made as follows: $\$ 44,500$, with the possibility of an increase to $£ 52,000$, to Dr. V. E. Cosslett, University lecturer in physics, University of Cambridge, to design and construct a very high voltage electron microscope and to explore its applications in biological and metallurgical research; $£ 1,000$, in supplement of a previous grant, to Prof. D. Gabor, professor of applied electron physics in the Imperial College, University of London, and Dr. D. Jones, for work on the development of an electron interference microscope; $£ 3,500$ to $\mathrm{Mr}$. D. W. Hill, research department of anæsthetics, Royal College of Surgeons of England, for the construction of an infrared gas or vapoux analyser using interference filters; $£ 2,500$ to Dr. N. Kurti, reader in physics and senior research Fellow, Brasenose College, Oxford, for the construction of a nuclear thermometer for use in the micro-degree Kelvin temperature-range; $£ 1,500$, in supplement of a previous grant, to Dr.J. H. Sanders, University lecturer and demonstrator in physics, Clarendon Laboratory, Oxford, for the construction of an optical maser. The Paul Instrument Fund Committee, composed of representatives of the Royal Society, the Institute of Physics and the Physical Society and the Institution of Electrical Engineers, was set up in 1945 "to receive applications from British subjects who are research workers in Great Britain for grants for the design, construction and maintenance of novel, unusual or much improved types of physical instruments and apparatus for investigations in pure or applied physical science".

\section{Department of Technical Co-operation}

IN a written answer in the House of Commons on November 14, the Secretary for Technical Co-opera. tion stated that of the expenditure on overseas information services, 32 per cent was attributable to the British Council, 35 per cent to the British Broadcasting Corporation, 13 per cent to the Central Office of Information and 20 per cent to overseas departments. The Department had taken over 87 administrative and advisory staff from other Departments, including 31 from one of the Overseas Departments, 155 executive staff, and 306 ancillary staff. With four exceptions, the staff had been previously employed on work which had been transferred with them. He was now considering how the Department's ability to help with advice on the economic aspects of development could be strengthened.

\section{Technical Colleges and Schools in Britain}

IN reply to a question in the House of Commons on November 16 regarding the number of technical colleges and schools in Great Britain, the Minister of Education, Sir David Eccles, said that in England and Wales there were 761 grant-aided major estab. lishments, 232 maintained secondary technical schools and 5 direct-grant secondary technical schools. Students in the two latter numbered 97,039 and 838 , respectively, in January 1961. In the 1959-60 sessions, 112,768 students attended full-time courses in the major establishments, 10,038 sandwich courses, 501,003 part-time and 784,584 evening courses. In the 92 major establishments in Scotland, there were 12,549 full-time students, 35,609 part-time and 52,696 evening students. Construction is in progress on 126 major projects in England and Wales and 18 in Scotland, and 217 further projects in England and Wales and 25 in Scotland have been approved.

\section{High-flux Reactor at Petten}

THE high-flux materials testing reactor at the Petten research centre of the Reactor Centrum Nederland became critical for the first time on November 9. This is the second reactor to become critical at Petten since September 28, 1960, when a low-flux reactor was put into operation. The nuclear part of the high-flux reactor was designed and delivered by the U.S. firm of Allis-Chalmers Manufacturing Company, the remaining part having been built in co-operation with several Dutch companies. Most components, also those delivered by AllisChalmers, were manufactured by Dutch industries. The reactor, which is essentially similar to the U.S. Oak Ridge research reactor, is intended for the testing of materials. The neutron beams emitted by the reactor can also be used for carrying out neutron physics research and for the production of radioisotopes. During the forthcoming months the reactor will be operated at low power. Afterwards the power will be gradually inereased up to the maximum level of $20,000 \mathrm{~kW}$. It is expected that this level will be reached in the spring of 1962 . In the meantime, the reactor vessel, in which the actual core of the reactor is situated, will be replaced by a new one, which has been manufactured in the United Kingdom.

\section{Digital Computation at King's College, Newcastle upon Tyne}

A NEW automatic digital computer has been ordered by King's College, Newcastle upon Tyne, to replace the Pegasus computer in the Computing Laboratory. The new computing system is based on the KDF.9 machine manufactured by the English Electric Company. A grant towards the cost of the machine has been promised by the University Grants Committee, while the balance remains to be found by the College. The new system is capable of very high speeds of calculation and has facilities for storing large quantitios of information on magnetic tape. Results in both numerical and alphabetical form can be printed, at speeds up to 600 lines per min. On some problems the new machine will operate at about one hundred times as fast as the existing machine, and will greatly assist many research projects in both pure and 